\title{
ДИНАМІКА ФОРМУВАННЯ ІХТІОФАУНИ САМАРСЬКОЇ ЗАТОКИ ПІД ВПЛИВОМ ФАКТОРІВ РІЗНОГО ПОХОДЖЕННЯ
}

На основі багаторічних досліджень іхтіофауни Самарської затоки (нижня течія р. Самара) встановлені основні закономірності розвитку угруповань риб Самарської затоки, здійснено оріснтовну оцінку впливу на цей процес різних за походженням та інтенсивністю факторів, запропоновано заходи щодо оптимізації умов відтворення іхтіофауни даної акваторії.

On the basis of the ichthyofauna perennial studies of the Samarsky bay (estuary of Samara river) main regularities of development of the local fish communities were ascertained. Approximate assessment of the influence of factors of various nature and intensity on this process was realized. Measures for optimization of the conditions of ichthyofauna recruitment were offered.

\section{Вступ}

Формування усіх біотичних компонентів Самарської затоки розпочалось одночасно з процесом залиття верхньої ділянки Дніпровського (Запорізького) водосховища після зведення греблі ДніпроГЕС (1929р.). По суті Самарська затока (нижня течія ріки) - частина Дніпровського водосховища, створена в 1933-1935 роках при заповненні гирлової частини ріки Самара. Після руйнування греблі ДніпроГЕС (1941р.), Самарська затока тимчасово припинила існування. Відновлена вона у 1947 році. За наявності спільних рис у процесах формування іхтіофауни даної акваторії та Дніпровського водосховища, існують певні відмінності гомеостазу їх іхтіокомплексів [2-4; 6; 14]. Специфіка гідроекологічних параметрів обумовила виділення затоки в окрему структурну одиницю районування - Крайове Самарське плесо [1]. Воно являе собою велику мілководну акваторію (понад 5 тис. га), створену у заплаві р. Самара зі значними показниками заростання водною рослинністю. Актуальність даної роботи полягає у тому, що, починаючи з 1955 року, не проводилося детальних фауністичних досліджень видового складу риб. Дані за період 1955-1981 років мають фрагментарний характер, стосуються в основному процесу промислового вилучення риб і не дають уявлення про напрямки формування видового складу іхтіофауни затоки. 31982 року проводяться щорічні моніторингові дослідження стану іхтіофауни. Дотепер не існувало повного зведення видового складу іхтіофауни першого етапу існування Сaмарської затоки (1935-1941рр.). Статус кожного з видів також наводиться вперше.

\section{Матеріал і методи досліджень}

Для аналізу стану та розвитку фауни риб Самарської затоки залучено публікації, архівні матеріали та джерела НДІ біології ДНУ [3-10; 13; 14], а також рукописні звіти інституту гідробіології. Іхтіологічні проби відібрані практично в усіх типах біотопів, у тому числі і трансформованих. Організація досліджень, відбір і подальша обробка отриманого матеріалу проводилися згідно 3 діючими іхтіологічними методиками [8; $11 ; 12]$. Систематика риб наведена з урахуванням останніх таксономічних змін [15].

\section{Результати та їх обговорення}

На поточний момент формування фауни риб Самарської затоки відбувається під впливом декількох масштабних факторів.

(C) О. О. Христов, В. М. Кочет, 2007

Вісник Дніпропетровського університету. Біологія, екологія.

Vìsnik Dnìpropetrovs'kogo unìversitetu. Seriâ Bìologiâ, ekologîâ Visnyk of Dnipropetrovsk University. Biology, ecology. Vìsn. Dnìpropetr. Unìv. Ser. Bìol. Ekol. 2007. 15(1).

ISSN 2310-0842 print ISSN 2312-301X online www.ecology.dp.ua 
1. Функціонування затоки в режимі водосховища (гідрологічний, гідрофізичний, гідрохімічний і гідробіологічний режими).

2. Надходження значних обсягів забруднених і недостатньо очищених стічних вод. Це високомінералізовані скиди шахт Центрального та Західного Донбасу, комунально-побутові та промислові стоки Павлограда, Новомосковська, лівобережжя Дніпропетровська, інших населених пунктів, розташованих по берегах Самари. Середньорічний обсяг скинутих стічних вод у р. Самару дорівнює 141,3 млн. м³/рік, що складає $28,9 \%$ природного стоку ріки.

3. Будівництво та функціонування гідротехнічних та інших споруд. Найнегативніше впливає на іхтіоценоз споруджена у 1970-ті роки автомагістраль "Харків Сімферополь" з одним вузьким мостовим переходом через русло Самари: насипна дамба дороги розітнула Самарську затоку, особливо іiі заплавну систему, суттєво змінивши тут гідроекологічну ситуацію. Це три мости в гирлі Самари, особливо Усть-Самарський міст, що практично відокремив акваторію затоки від водосховища; різного типу шляхопроводи через р. Самара, включаючи високовольтні ЛЕП.

4. Високий рівень забудови, промислового та цивільного будівництва, господарська діяльність у водоохоронній і прибережній мілководній зоні.

5. Забір води та функціонування водозабірних споруд.

6. Аматорське та промислове рибальство, а також форми незаконного вилову риби, особливо браконьєрство, включаючи найнебезпечніший для іхтіоценозу його вид - так звану “електровудку”.

7. Рекреаційне засвоєння акваторії та прибережної зони.

У цілому, Самарська затока, загальною площею 5702 га, характеризується мілководністю (середні глибини - менше 2 м) і високим ступенем заростання як жорсткою надводною, так і м'якою підводною вищою водною рослинністю (у середньому заростання складає 45 \%). Середня ширина плеса складає 2 км, площа мілководь - 57,9 \% акваторії [2]. Центральна частина плеса зайнята фітоценозами зануреної рослинності.

Верхня частина затоки практично цілком відрізана дамбою автомагістралі “Харків - Сімферополь” і пов'язана з іншою частиною затоки тільки за допомогою русла р. Самара. Це стало причиною деградації нерестовищ на більшості ділянок заплави вище й нижче дамби, їх непридатності для відтворення більшості представників аборигенного іхтіоценозу, особливо 3 фітофільної групи, у тому числі функціонально та ресурсно значимих видів риб.

У зв'язку зі зниженням і практично припиненням вантажних і пасажирських перевезень водним транспортом у даний час відбувається подальше обміління й заростання руслової частини Самари, по якій був прокладений судовий хід (фарватер).

Перші гідробіологічні та іхтіологічні дослідження нижньої течії р. Самара (майбутньої Самарської затоки) проведені у 1929 році під час роботи експедиції Дніпропетровської гідробіологічної станції. Але існуючі джерела [7] деталізовано описують стан фауни риб порожистої частини р. Дніпро (суміжної гирлу р. Самара акваторії). Дані щодо стану іхтіофауни саме гирлової частини р. Самара до спорудження ДніпроГЕС відсутні, існують лише свідчення щодо загального складу риб гирлової частини р. Самари - 30 видів без їх переліку [10]. На той час іхтіокомплекс порожистої частини p. Дніпро складався із 47 видів видів риб [7]. Можливо, що частка видівреофілів використовувала акваторію нижньої ділянки р. Самара для нересту, тобто тимчасово. Перші деталізовані дані про стан фауни риб Самарської затоки датуються періодом існування гирла p. Самара після катастрофічного спаду води (1941-1946рp.) i періодом подальшого відновлення Самарської затоки в режимі водосховищного типу функціонування (після відбудови греблі ДніпроГЕС, 1947-1955рр.) [10; 14].

Вісник Дніпропетровського університету. Біологія, екологія.

Vìsnik Dnìpropetrovs'kogo unìversitetu. Serìa Bìologiâ, ekologiâ Visnyk of Dnipropetrovsk University. Biology, ecology. Vìsn. Dnìpropetr. Unìv. Ser. Bìol. Ekol. 2007. 15(1).

ISSN 2310-0842 print ISSN 2312-301X online www.ecology.dp.ua 
Після утворення Дніпровського водосховища (перший етап існування Самарської затоки) відбулася певна перебудова іхтіоценозу, зміна видового складу та параметрів усіх груп водної флори та фауни. Але якісної заміни реофільного комплексу на лімнофільний, як це відбулося у суміжній акваторії порожистої частини p. Дніпро, не зареєстровано. Аналіз архівних даних, публікацій та звітів свідчить про те, що гирло р. Самара і до створення Самарської затоки (1933-1935 рр.) являло собою три рукави із затоками 3 уповільненою течією. Тут первинно домінував лімнофільний екологічний комплекс. Такі реофільні прохідні та напівпрохідні види, як осетер (Acipenser gueldenstaedtii Brandt \& Ratzeburg, 1833), севрюга (A. stellatus Pallas, 1771), білуга (Huso huso ponticus Salnikov \& Malatsky, 1934), оселедець чорноморсько-азовський прохідний (Alosa pontica Eichwald, 1838), вирезуб (Rutilus frisii (Nordmann, 1840)), рибець (Vimba vimba Linnaeus, 1758) заходили у гирло р. Самара навесні для нересту [10]. Тому зараховувати їх до складу постійної (аборигенної) фауни риб затоки некоректно.

Зведення свідчень різних джерел дозволили констатувати, що у перший період існування Самарської затоки (1935-1941рр.) на іï акваторії мешкало 34 види риб, абсолютну більшість яких складали лімнофіли із домінуванням комплексу плітки (Rutilus rutilus Linnaeus, 1758), ляща звичайного (Abramis brama Linnaeus, 1758), окуня річкового (Perca fluviatilis Linnaeus, 1758), лина озерного (Tinca tinca Linnaeus, 1758), щуки (Esox lucius Linnaeus, 1758), краснопірки (Scardinius erythrophthalmus Linnaeus, 1758) та карася звичайного (Carassius carassius Linnaeus, 1758), а 3 непромислових видів - з верховодки (Alburnus alburnus Linnaeus, 1758) та гірчака (Rhodeus sericeus Pallas, 1776) (табл.).

Другий етап (1941-1946 рр.) характеризується частковим відновленням річкового режиму після руйнування греблі ДніпроГЕС у 1941 році. Зазначимо, що руйнування було не повним: прохідні види з понизь Дніпра не мали змоги піднятися вище греблі. Через відсутність необхідних умов (понад усе - швидкої течії) реофільний комплекс не сформувався. Як указувалося раніше, гирло р. Самара i до затоплення являло собою мережу акваторій різної конфігурації з уповільненою течією та значно зарослими вищою водною рослинністю мілководдями. Деякі види-реофіли використовували ії частково, під час нересту. У цей період видовий склад в основному зберігся. Відмічається зменшення чисельності більшості промислових видів i зниження обсягів вилову. Загалом у даний період зареєстровано 31 вид риб. Не зареєстровано типових реофільних риб - підуста (Chondrostoma nasus Linnaeus, 1758), синця (Abramis ballerus Linnaeus, 1758) та клепця (A. sapa Pallas, 1814). Уперше встановлено гольяна озерного (Phoxinus perenurus Pallas, 1814).

Третій етап існування затоки (1947-1955 роки) почався після відновлення греблі ДніпроГЕС у 1947 році. Залиття великих мілководних площ обумовило в той період бурхливий розвиток існуючих на даній акваторії видів. Їх налічувалося 30. Відновила своє існування чехоня (Pelecus cultratus Linnaeus, 1758). Поступово зменшують чисельність підуст звичайний і носар (Gymnocephalus acerinus Güldenstädt, 1774). Крім наведених вище риб, які зникли у перші роки існування затоки, тут востаннє були зареєстровані ялець звичайний (Leuciscus leuciscus leuciscus Linnaeus, 1758), підуст звичайний, носар, пуголовка зірчаста (Benthophilus stellatus Sauvage, 1874). Інші види продовжують реєструватися з певним поширенням на наново залитих акваторіях.

Четвертий етап (1955-2006 pp.). Починається поступове нарощування обсягів і масштабів експлуатації природних ресурсів Самарської затоки та суміжних територій, а також значно посилюється антропогенний тиск.

Вісник Дніпропетровського університету. Біологія, екологія.

Vìsnik Dnìpropetrovs'kogo unìversitetu. Serîâ Bìologîa, ekologiâ Visnyk of Dnipropetrovsk University. Biology, ecology. Vìsn. Dnìpropetr. Unìv. Ser. Bìol. Ekol. 2007. 15(1).

ISSN 2310-0842 print ISSN 2312-301X online www.ecology.dp.ua 
До початку інтенсивного промислового та сільськогосподарського освоєння регіону Самарська затока була найважливішим місцем нересту ресурсних видів риб та місцем нагулу їх молоді. Під впливом антропогенної трансформації затоки починається деградація природних нерестовищ. Загальний склад іхтіофауни нараховує 37 видів. Спостерігається поступова елімінація деяких видів (підуста звичайного, синця, в'язя (Leuciscus idus Linnaeus, 1758)) та появою нових за рахунок інтродукційних робіт і саморозселення (за рахунок видів китайського рівнинного комплексу - товстолобика білого (Hypophthalmichthys molitrix Valenciennes, 1844) та строкатого (Aristichthys nobilis Richardson, 1846), амура білого (Ctenopharyngodon idella Valenciennes, 1844), а також непромислового функціонально небезпечного чебачка амурського (Pseudorasbora parva Temminck \& Shlegel, 1846), $з$ північноамериканського комплексу - сомика канального американського (Ictalurus punctatus Rafinesque, 1818)). 3 понизь Дніпра проник берш (Stizostedion volgense Gmelin, 1788), інтенсивно поширюються представники солонуватоводної фауни понтокаспійського морського комплексу - тюлька чорноморсько-азовська (Clupeonella cultriventris Nordmann, 1840), морська голка (Syngnathus abaster nigrolineatus Eichwald, 1831), бичок кнут (Mesogobius batrachocephalus Pallas, 1814), бичок гонець (Neogobius gymnotrachelus Kessler, 1857), бичок кругляк (N. melanostomus Pallas, 1814). Інвазійний процес нерозривно пов'язаний iз генезисом іхтіофауни усього Дніпровського водосховища. Формування іхтіокомплексу продовжується й у сучасний період.

Незважаючи на збереження вихідного лімнофільного видового складу риб, у зв'язку із зростанням рівня антропогенного впливу починаючи з 1960-х років і по теперішній час, значення Самарської затоки (у плані відтворення іхтіофауни) суттєво зменшилось. Зручне розташування затоки (нижня частина в межах м. Дніпропетровськ) обумовило високий рівень рекреаційного навантаження, у тому числі аматорського рибальства (організованого та неорганізованого). Серед чинників, несприятливих для рибного населення, слід відзначити високий рівень заростання акваторії затоки вищою водною рослинністю. У даний час мілководдя, що повністю заростають повітряно-водною рослинністю, практично не функціонують у літній період як місця нагулу молоді риб і лише частково використовуються для нагулу такими видами як лин, карась сріблястий (Carassius auratus gibelio Bloch, 1782) та золотий, краснопірка, окунь. Продовжують нарощувати чисельність функціонально небезпечні види: гірчак, чебачок амурський, із короткоциклових - верховодка та вівсянка (Leucaspius delineatus Heckel, 1843).

У даний час в іхтіофауні Самарської затоки переважають види понтокаспійського прісноводного (12 видів) та понтокаспійського морського (10 видів) фауністичних комплексів. Представники бореального рівнинного комплексу нараховують 7 видів, до третинного рівнинного прісноводного комплексу належать 5 видів, китайського рівнинного - 4, арктичного морського, арктичного прісноводного, та північноамериканського прісноводного комплексів - по одному виду.

У трофічному відношенні структура іхтіоценозу значно спрощена. У прибережних угрупованнях домінують за іхтіомасою еврифаги (більше 50 \%) та бентофаги (до 40 \%). Інші групи малозначимі: в основному це представники групи хижаків.

Прибережні угруповання риб - чутливі індикатори стану як усього іхтіоценозу, так і окремих популяцій. За чисельними параметрами щорічних генерацій визначається не тільки реалізація відтворювального циклу, а й умови нагулу даної когорти. За даними сучасних досліджень (2001-2006 рр.), чисельність риб прибережних угруповань коливалася в межах 258,1-1235,9 екз./100 м², що $\epsilon$ відносно малим показником і свідчить про загальні несприятливі умови відтворення. Слід врахувати, що у

Вісник Дніпропетровського університету. Біологія, екологія.

Vìsnik Dnìpropetrovs'kogo unìversitetu. Serîâ Bìologîa, ekologiâ Visnyk of Dnipropetrovsk University. Biology, ecology. Vìsn. Dnìpropetr. Unìv. Ser. Bìol. Ekol. 2007. 15(1).

ISSN 2310-0842 print ISSN 2312-301X online www.ecology.dp.ua 
2001 році чисельність більшості ресурсних видів була максимальною за останній час. Внаслідок несприятливих умов існування та напружених трофічних відносин у прибережжі, жорсткої конкуренції між прибережноводними видами (молодь і статевозрілі особини) і молоддю інших видів (вікові групи 0+-2+) загальна чисельність більшості видів із категорії ресурсних зменшується. Показники іхтіомаси також характеризується зниженням. У складі молоді ресурсних видів домінують еврибіонти плітка та карась сріблястий. Із непромислових видів численні гірчак, морська голка, бичок цуцик (Proterorhinus marmoratus Pallas, 1814), які не мають господарської цінності, є трофічними конкурентами молоді. Крім того, вони живляться ікрою та личинками промислових видів риб. Загальна чисельність молоді в Самарській затоці менша, ніж у цілому по водосховищу. У складі іхтіофауни види з категорії промислово цінних (лящ і судак) складають до 8,5 \%. За чисельністю домінують непромислові види - до 83,1\%. В іхтіоценозі прибережних ділянок домінують види, що не мають господарського значення або відносяться до категорії малоцінних. На першому місці перебуває функціонально небезпечний вид - гірчак (до 66,7 \% загальної чисельності іхтіоценозу).

Аналіз багаторічних даних стану риб прибережних угруповань свідчить про значні коливання чисельності у різні роки досліджень. При цьому суттєвого збіднення видового складу, порівняно з 1955 роком, не відбулося. Але, судячи 3 динаміки чисельності та поширення видів по акваторії затоки, можна констатувати загальний нестійкий стан іхтіокомплексу, значний вплив негативних факторів, більша частина яких обумовлена функціонуванням у режимі водосховища. Самарська затока $\epsilon$, за всіма видами навантаження, інтенсивно експлуатованим районом. Нагульну функцію для більшості молоді та старших генерацій зареєстрованих видів зберегла лише частина затоки. Продовжується деградація потужних у минулому ії нерестовищ. У поточний час ефективно використовують дану акваторію як нерестовище лише декілька видів. Це карась сріблястий і звичайний, краснопірка, окунь, лин, щука, плоскирка звичайна (Blicca bjoerkna Linnaeus, 1758), частково - плітка та лящ, в останні роки - судак.

Загалом, більшість показників, що характеризують стан іхтіоценозу, свідчать про певну спрощеність його структури, невелику частку видів із категорії водних живих ресурсів, відсутність в окремі роки молоді промислово цінних видів у контрольних обловах, великий відсоток видів, що відносяться до групи функціонально небезпечних, які є трофічними конкурентами молоді видів ресурсної групи. Все це обумовлює понижену екологічну та рибогосподарську цінність Самарської затоки на сучасному етапі. При існуючому рівні відновних процесів, що проходять на акваторії Самарської затоки, перспектива природного (без оптимізуючого втручання) поліпшення стану функціонально й у промисловому відношенні важливих видів даної акваторії практично відсутня. Значна частка видів має статус обмежено розповсюджених, реєструються одиничні особини. Подальша деградація нерестовищ і нагульних акваторій призведе до зміни іхтіоценозу. Для відновлення ролі Самарської затоки у процесі сталого розвитку іхтіофауни регіону необхідне оптимізуюче втручання. Допустимі та першочергові наступні заходи.

1. Гідромеханізовані (днопоглиблювальні) роботи з видаленням мулових відкладень. Необхідно проводити розчищення тільки безпосередньо руслової частини, зі збереженням природних меандрів без порушення порід, які підстилають дно, відновлення водообміну у заплавній частині, збереження прибережної зони та корінних берегів. Складувати мулові відкладення необхідно за межами водоохоронної смуги на відстані, достатній для запобігання вторинного забруднення. Оптимальні строки проведення робіт - осінньо-зимовий період.

Вісник Дніпропетровського університету. Біологія, екологія.

Vìsnik Dnìpropetrovs'kogo unìversitetu. Serîâ Bìologîa, ekologiâ Visnyk of Dnipropetrovsk University. Biology, ecology. Vìsn. Dnìpropetr. Unìv. Ser. Bìol. Ekol. 2007. 15(1).

ISSN 2310-0842 print ISSN 2312-301X online www.ecology.dp.ua 
Видовий склад іхтіофауни Самарської затоки

\begin{tabular}{|c|c|c|c|c|c|c|}
\hline \multirow[b]{2}{*}{ № } & \multirow[b]{2}{*}{ Назва виду } & \multicolumn{5}{|c|}{ Етапи формування екосистеми Самарської затоки } \\
\hline & & $\begin{array}{c}1935- \\
1941 \mathrm{pp} .\end{array}$ & $\begin{array}{c}1941- \\
1946 \mathrm{pp} .\end{array}$ & $\begin{array}{c}1947- \\
1955 \mathrm{pp} .\end{array}$ & $\begin{array}{c}1991- \\
2006 \mathrm{pp} .\end{array}$ & статус \\
\hline 1 & 2 & 3 & 4 & 5 & 6 & 7 \\
\hline 1 & $\begin{array}{l}\text { Мінога українська } \\
\text { (Eudontomyzon mariae Berg, 1931) }\end{array}$ & + & + & - & - & HP \\
\hline 2 & $\begin{array}{l}\text { Тюлька чорноморсько-азовська (Clupeonella } \\
\text { cultriventris cultriventris Nordmann, 1840) }\end{array}$ & - & - & - & + & $\mathrm{M} / \Pi \mathrm{P}$ \\
\hline 3 & $\begin{array}{l}\text { Амур білий } \\
\text { (Ctenopharyngodon idella Valenciennes, 1844) }\end{array}$ & - & - & - & $+*$ & ПО \\
\hline 4 & $\begin{array}{l}\text { Вівсянка (верхівка) } \\
\text { (Leucaspius delineatus Heckel, 1843) }\end{array}$ & + & $+1+$ & ++ & H & Н/П ШР \\
\hline 5 & Гірчак (Rhodeus sericeus Pallas, 1776) & $+1+$ & $+1+$ & $+1+$ & $+1+$ & Н/П ШР \\
\hline 6 & $\begin{array}{l}\text { Плоскирка звичайна } \\
\text { (Blicca bjoerkna Linnaeus, 1758) }\end{array}$ & + & $+1+$ & H+ & + & П ШР \\
\hline 7 & В'язь звичайний (Leuciscus idus Linnaeus, 1758) & ++ & ++ & ++ & - & $\mathrm{HP}$ \\
\hline 8 & Головень (Leuciscus cephalus Linnaeus, 1758) & ++ & ++ & ++ & + & ПОР \\
\hline 9 & $\begin{array}{l}\text { Ялець звичайний } \\
\text { (Leuciscus leuciscus Linnaeus, 1758) }\end{array}$ & + & ++ & + & - & HP \\
\hline 10 & Білизна (Aspius aspius Linnaeus, 1758) & + & + & + & + & ПОР \\
\hline 11 & $\begin{array}{l}\text { Карась звичайний (золотий) } \\
\text { (Carassius carassius Linnaeus, 1758) }\end{array}$ & $+1+$ & $+1+$ & $+1+$ & + & ПР \\
\hline 12 & $\begin{array}{l}\text { Карась сріблястий } \\
\text { (Carassius auratus gibelio Bloch, 1782) }\end{array}$ & - & - & - & $+1+$ & ПШР \\
\hline 13 & Підуст (Chondrostoma nasus Linnaeus, 1758) & ++ & - & $+*$ & - & HP \\
\hline 14 & Короп (сазан) (Cyprinus caprio Linnaeus, 1758) & ++ & $+\mathrm{H}$ & ++ & ++ & ЦПШР \\
\hline 15 & $\begin{array}{l}\text { Краснопірка } \\
\text { (Scardinius erythrophthalmus Linnaeus, 1758) }\end{array}$ & H+ & $+1+$ & $+1+$ & $+1+$ & ПШР \\
\hline 16 & Синець (Abramis ballerus Linnaeus, 1758) & ++ & - & - & - & $\mathrm{HP}$ \\
\hline 17 & Лящ звичайний (Abramis brama Linnaeus, 1758) & $+1+$ & $+1+$ & $+1+$ & ++ & ЦПШР \\
\hline 18 & Клепець (Abramis sapa Pallas, 1814) & ++ & - & - & - & $\mathrm{HP}$ \\
\hline 19 & $\begin{array}{l}\text { Лин звичайний (озерний) } \\
\text { (Tinca tinca Linnaeus, 1758) }\end{array}$ & +1+ & $+1+$ & $+1+$ & H & ПШР \\
\hline 20 & Пічкур звичайний (Gobio gobio Linnaeus, 1758) & ++ & ++ & ++ & + & $\mathrm{H} / \Pi \mathrm{OP}$ \\
\hline 21 & $\begin{array}{l}\text { Товстолобик строкатий } \\
\text { (Aristichthys nobilis Richardson, 1846) }\end{array}$ & - & - & - & + & П ШР \\
\hline 22 & Плітка звичайна (Rutilus rutilus Linnaeus, 1758) & $++1+$ & $++1+$ & $+1+$ & $+1+$ & ПШР \\
\hline 23 & $\begin{array}{l}\text { Товстолобик білий } \\
\text { (Hypophthalmichthys molitrix Valenciennes, 1844) }\end{array}$ & - & - & - & + & ПШР \\
\hline 24 & Верховодка (Alburnus alburnus Linnaeus, 1758) & $+\mathrm{H+}$ & $++1+$ & $+\mathrm{H+}$ & $+\mathrm{H+}$ & М/ПШР \\
\hline 25 & $\begin{array}{l}\text { Чебачок амурський (Pseudorasbora parva } \\
\text { Temminck \& Shlegel, 1846) }\end{array}$ & - & - & - & + & Н/П ШР \\
\hline 26 & Чехоня (Pelecus cultratus Linnaeus, 1758) & ++ & - & ++ & + & $\Pi \mathrm{O}$ \\
\hline 27 & Гольян озерний (Phoxinus perenurus Pallas, 1814) & - & $+*$ & - & - & $\mathrm{HP}$ \\
\hline 28 & \begin{tabular}{|l} 
Голець вусатий (слиж звичний) \\
(Barbatula barbatula Linnaeus, 1758)
\end{tabular} & + & + & - & - & HP \\
\hline 29 & $\begin{array}{l}\text { В'юн звичайний } \\
\text { (Misgurnus fossilis Linnaeus, 1758) }\end{array}$ & + & - & ++ & + & Н/П ОР \\
\hline 30 & Щипавка звичайна (Cobitis taenia Linnaeus, 1758) & ++ & ++ & ++ & ++ & Н/П ШР \\
\hline 31 & Сом звичайний (Silurus glanis Linnaeus, 1758) & ++ & $+\mathrm{H}$ & ++ & + & $\Pi \mathrm{O}$ \\
\hline 32 & $\begin{array}{l}\text { Сомик канальний американський } \\
\text { (Ictalurus punctatus Rafinesque, 1818) }\end{array}$ & - & - & - & + & ПО \\
\hline 33 & Щука (Esox lucius Linnaeus, 1758) & $+1+$ & +++ & $+1+$ & $+1+$ & ПШР \\
\hline 34 & Минь річковий (Lota lota Linnaeus, 1758) & ++ & ++ & ++ & + & П ОР (X-II) \\
\hline
\end{tabular}

Вісник Дніпропетровського університету. Біологія, екологія.

Vìsnik Dnìpropetrovs'kogo unìversitetu. Serìa Bìologiâ, ekologiâ Visnyk of Dnipropetrovsk University. Biology, ecology. Vìsn. Dnìpropetr. Unìv. Ser. Bìol. Ekol. 2007. 15(1).

ISSN 2310-0842 print ISSN 2312-301X online www.ecology.dp.ua 
Khrystov O. O., Kochet V. M.

Dynamics of the ichthyofauna formation in the Samarsky bay under influence of different factors

Закінчення табл.

\begin{tabular}{|c|c|c|c|c|c|c|}
\hline 1 & 2 & 3 & 4 & 5 & 6 & 7 \\
\hline 35 & $\begin{array}{l}\text { Атерина чорноморська } \\
\text { (Atherina boyeri pontica Eichwald, 1831) }\end{array}$ & - & - & - & ++ & $\mathrm{H} / \Pi \mathrm{P}$ \\
\hline 36 & $\begin{array}{l}\text { Колючка триголкова } \\
\text { (Gasterosteus aculeatus Linnaeus, 1758) }\end{array}$ & - & - & - & + & Н/П ОР \\
\hline 37 & $\begin{array}{l}\text { Колючка мала південна } \\
\text { (Pungitius platygaster Kessler, 1859) }\end{array}$ & + & ++ & - & ++ & Н/П ШР \\
\hline 38 & $\begin{array}{l}\text { Морська голка пухлощока чорноморська } \\
\text { (Syngnathus abaster nigrolineatus Eichwald, 1831) }\end{array}$ & - & - & - & ++ & $\mathrm{H} / \Pi \mathrm{P}$ \\
\hline 39 & $\begin{array}{l}\text { Йорж звичайний } \\
\text { (Gymnocephalus cernuus Linnaeus, 1758) }\end{array}$ & + & $+1+$ & $+1+$ & + & $\mathrm{H} / \Pi \mathrm{P}$ \\
\hline 40 & Окунь річковий (Perca fluviatilis Linnaeus, 1758) & $+1+$ & +++ & $+1+$ & $+1+$ & ПШР \\
\hline 41 & Hocap (Gymnocephalus acerinus Güldenstädt, 1774) & ++ & ++ & $+*$ & - & $\mathrm{HP}$ \\
\hline 42 & Берш (Stizostedion volgense Gmelin, 1788) & - & - & - & + & $\Pi \mathrm{O}$ \\
\hline 43 & $\begin{array}{l}\text { Судак звичайний } \\
\text { (Stizostedion lucioperca Linnaeus, 1758) }\end{array}$ & + & ++ & ++ & + & Ц/П ОР \\
\hline 44 & $\begin{array}{l}\text { Бичок пуголовка зірчаста } \\
\text { (Benthophilus stellatus Sauvage, 1874) }\end{array}$ & + & $+*$ & $+*$ & - & HP \\
\hline 45 & $\begin{array}{l}\text { Бичок мартовик (кнут) } \\
\text { (Mesogobius batrachocephalus Pallas, 1814) }\end{array}$ & - & - & - & ++ & $\mathrm{H} / \Pi \mathrm{P}$ \\
\hline 46 & $\begin{array}{l}\text { Бичок бабка річкова (пісочник) } \\
\text { (Neogobius fluviatilis Pallas, 1814) }\end{array}$ & $+1+$ & $+1+$ & $+1+$ & $+1+$ & Н/П ШР \\
\hline 47 & $\begin{array}{l}\text { Бичок головач (Кеслера) } \\
\text { (Neogobius kessleri Gunter, 1861) }\end{array}$ & + & ++ & ++ & ++ & Н/П ШР \\
\hline 48 & $\begin{array}{l}\text { Бичок гонець } \\
\text { (Neogobius gymnotrachelus Kessler, 1857) }\end{array}$ & - & - & - & ++ & H/П OP \\
\hline 49 & $\begin{array}{l}\text { Бичок кругляк } \\
\text { (Neogobius melanostomus Pallas, 1814) }\end{array}$ & - & - & - & + & Н/ПР \\
\hline 50 & \begin{tabular}{|l|} 
Бичок цуцик \\
(Proterorhinus marmoratus Pallas, 1814)
\end{tabular} & $+1+$ & $+1+$ & ++ & + & Н/П Р \\
\hline
\end{tabular}

Примітки: представленість видів за чисельністю: +++ - поширений, численний вид, ++ - поширений, типовий вид, + - вид утворює локальні популяції, +*- зареєстровано одиничні екземпляри; ресурсне значення: Ц/П - цінний промисловий вид, П - промисловий вид, М/П - малоцінний промисловий вид, Н/П - непромисловий вид; розповсюдження: ШР - широкорозповсюджені, $\mathrm{P}$ - розповсюджені, ОР - обмеженорозповсюджені види, НР - вид не реєструється; статус: X - види, які мають регіональний охоронний статус і занесені до Червоного списку Дніпропетровської області, II - вразливі види, IV - невизначені види.

2. Регулювання процесу користування водними живими ресурсами шляхом залучення або заборони використання певних знарядь лову та визначення оптимальних обсягів вилучення, районів для промислового та аматорського рибальства.

3. Припинення процесу забудови прибережної зони та обмеження ії використання в господарських цілях. Даний процес діяльності можливо регулювати винятково за науково обгрунтованими висновками з урахуванням розмірів навантаження та обов' язковими компенсаційними заходами.

Вказані заходи відповідають розповсюдженим у міжнародній практиці засобам оптимізації порушених гідроекосистем [16]. Пропозиції з оптимізації іхтіоценозу частково впроваджуються через систему біологічних обгрунтувань і рекомендацій 3 експлуатації водних живих ресурсів у Самарській затоці.

Рекомендації щодо поліпшення загальноекологічного стану даної акваторії і iii іхтіофауни шляхом заборони скиду промислових і побутових забруднювачів, скорочення обсягів надходження шахтних вод у даній статті не розглядаються, тому що на сучасному етапі розвитку економіки їх упровадження неможливе.

Вісник Дніпропетровського університету. Біологія, екологія.

Vìsnik Dnìpropetrovs'kogo unìversitetu. Serìa Bìologiâ, ekologiâ Visnyk of Dnipropetrovsk University. Biology, ecology. Vìsn. Dnìpropetr. Unìv. Ser. Bìol. Ekol. 2007. 15(1)

ISSN 2310-0842 print ISSN 2312-301X online www.ecology.dp.ua 


\section{Висновки}

1. У даний час (1991-2006 рр.) у Самарській затоці із 50 видів, які зареєстровано 3 початку іiі існування, встановлено 40 видів риб. За період із 1955 року у видовому складі не реєструється 6 видів-реофілів. Поповнення відбулося за рахунок видів китайського рівнинного (4 види), понтокаспійського морського та понтокаспійського прісноводного (8), бореально рівнинного (1) фауністичних комплексів - загалом 13 видів, усі представники лімнофільної екологічної групи. Наявність представника північноамериканської фауни (сомика канального) обумовлена тимчасовим надходженням його з біотопів підігрітих скидних вод Придніпровської ТЕС.

2. Вважати реофільний комплекс вихідним на даній акваторії некоректно. Гирло p. Самара i до зарегулювання було значно зарослим із невисокою швидкістю течії, базовим тут був і залишається лімнофільний комплекс. Цей комплекс із збереженням стабілізованого видового складу функціонував до початку 1960-х років. Пізніше, під впливом антропогенних факторів, починається поступова деградація іхтіоценозу, але в основному на рівні зменшення чисельності функціонально та ресурсно важливих видів.

3. Самарська затока має відповідний рибогосподарський потенціал і можливості відтворення видів ресурсного комплексу. Але він знижений порівняно 3 першими роками існування затоки. Дана акваторія поступово продовжує деградувати як природне нерестовище. Найефективніше відтворюються лише декілька видів - карасі сріблястий та золотий, лин, щука, плоскирка, окунь, частково - плітка, судак та лящ.

4. Значна частка молоді зареєстрованих видів має невисокі показники чисельності й обмежене розповсюдження. Подальша деградація нерестовищ і нагульних акваторій може спричинити зниження рівня біологічного різноманіття.

5. Основним фактором негативного впливу на іхтіоценоз $\epsilon$ інтенсифікація процесу господарської діяльності, яка має комплексний і багатоплановий характер. Для відновлення і оптимізації іхтіоценозу необхідне проведення заходів оптимізуючого втручання, першочерговими 3 яких мають бути гідромеханізовані роботи, науково обгрунтоване регулювання процесів господарської діяльності у водоохоронній смузі, рекреаційного навантаження та використання водних живих ресурсів.

\section{Бібліографічні посилання}

1. Барановский Б. А. Растительность руслового равнинного водохранилища.- Д.: Вид-во ДНУ, 2000. - С. 17-29.

2. Есипова Н. Б. Эколого-физиологическая характеристика рыб, обитающих в зоне антропогенного загрязнения / Н. Б. Есипова, Т. С. Шарамок, Е. В. Федоненко // Наукові записки. Серія біологія. - Тернопіль: Вид-во Тернопільського педагогічного університету, 2005.- № 3 (26). - C. 150-152.

3. Загубіженко Н. І. Використання донних безхребетних р. Самари в якості індикаторів антропогенного навантаження на екосистеми ріки / Н. І. Загубіженко, В. М. Кочет, О. О. Христов // Вісник Дніпропетровського університету. Біологія, екологія. - Д.: ДНУ, 2004. - Вип. 12 , т. 1. - С. 50-54.

4. Кочет В. М. Використання індикаторних можливостей угруповань риб для оцінки рівня впливу шахтних вод на екосистему р. Самари // Вісник Дніпропетровського університету. Біологія, екологія. - Д.: ДНУ, 2004. - Вип. 12, т. 1. - С. 76-81.

5. Кочет В. М. Фауна риб техногенних акваторій, суміжних басейну р. Самари, в умовах гіпермінералізації середовища мешкання // Вісник Дніпропетровського університету. Біологія, екологія. - Д.: ДНУ, 2005. - Вип. 13, т. 1. - С. 118-123.

6. Кочет В. М. Исследование некоторых структурно-функциональных особенностей сообществ гидрофауны р. Самары Днепровской / В. М. Кочет, С. Н. Тарасенко, Н. И. Загубиженко // Bicник Дніпропетровського університету. Біологія, екологія. - Д.: ДНУ, 1997. - Вип. 3. - С. 94-101.

7. Короткий Й. І. Іхтіофауна порожистої частини Дніпра та ії зміни під впливом побудування Дніпрельстану. - Д., 1937. - Т. 2. - С. 133-141.

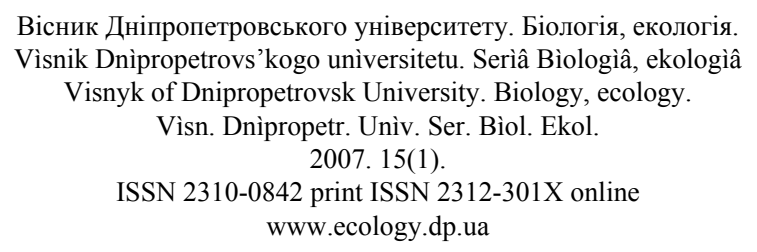


8. Кузнецов В. Л. Количественный учет молоди в водохранилищах и озерах (Методические подходы и возможности) // Типовые методики исследования продуктивности видов рыб в пределах их ареалов. - Вильнюс, 1985. - Ч. 5. - С. 26-35.

9. Кулик А. Ф. Вариант экологической оценки состояния р. Самара / А. Ф. Кулик, Л. В. Доценко, В. Н. Кочет, Ю. П. Бобылев // Вісник Дніпропетровського університету. Біологія, екологія. - Д.: ДНУ, 2003. - Вип. 11, т. 1. - С. 24-31.

10. Мельников Г. Б. Изменение ихтиофауны р. Самары в результате катастрофического спада воды // Г. Б. Мельников, А. Ф. Коблицкая // Вестник Днепропетровского научноисследовательского института гидробиологии. - К.: КГУ, 1948. - Т. 8. - С. 131-135.

11. Методика збору і обробки іхтіологічних і гідробіологічних матеріалів з метою визначення лімітів промислового вилучення риб із великих водосховищ і лиманів України. - К.: ІРГ УААН, 1998. - 47 с.

12. Правдин И. Ф. Руководство по изучению рыб (преимущественно пресноводных). - М.: Пищевая промышленность, 1966. - 376 с.

13. Свиренко Д. О. Значення, завдання, план, програма та хід гідробіологічних досліджень порожистої частини р. Дніпро в зв’язку з побудуванням греблі Дніпрельстану // Вісник Дніпропетровської гідробіологічної станції. - Д., 1937. - Т. 2. - С. 3-11.

14. Чаплина А. М. Ихтиофауна Самарского водохранилища после его восстановления // Вестник Днепропетровского научно-исследовательского института гидробиологии. - К.: КГУ, 1955. - Т. 11. - С. 155-162.

15. Щербуха А. Я. Українська номенклатура іхтіофауни України. - К.: Зоомузей ННПМ НАН України, 2003. - 48 с.

16. The restoration of rivers and streams. Theories and experience // Ed. J. A. Gore. - BostonLondon: Butterworh publishers, 1985. - $318 \mathrm{c}$.

Надійшла до редколегії 10.02.2007

Вісник Дніпропетровського університету. Біологія, екологія.

Vìsnik Dnìpropetrovs'kogo unìversitetu. Seriâ Bìologîa, ekologîâ

Visnyk of Dnipropetrovsk University. Biology, ecology. Vìsn. Dnìpropetr. Unìv. Ser. Bìol. Ekol. 2007. 15(1).

ISSN 2310-0842 print ISSN 2312-301X online www.ecology.dp.ua 